\title{
Tindak Pidana Illegal Fishing di Perairan Natuna Dalam Perspektif Kriminologi
}

\author{
${ }^{1}$ Punik Triesti Wijayanti, ${ }^{2}$ Dhea Putri Sri Wahyuniarti, ${ }^{3}$ Riska Andi Fitriono \\ ${ }^{1}$ Fakultas Hukum, Universitas Sebelas Maret Surakarta \\ Email : puniktriesti@gmail.com \\ ${ }^{2}$ Fakultas Hukum, Universitas Sebelas Maret Surakarta \\ Email : dheawahyuniartii@gmail.com \\ ${ }^{3}$ Fakultas Hukum, Universitas Sebelas Maret Surakarta \\ Email : riskaandi@staff.uns.ac.id
}

\begin{abstract}
Indonesia is a country with a sea area that is very spacious with an abundance of a diversity of riches of the sea in it. The breadth of the territorial sea as well as the many riches of the sea caused many sea regions of Indonesia that often become the place of action illegal fishing, especially around the sea that borders with other countries. One of them is the Natuna sea in the Province of Riau Islands, Indonesia. Types of research method used is case study research with a descriptive approach in outlining the problems faced related to Illegal fishing activities in the Natuna sea. The result show that this illegal fishing activity is mostly carried out by foreign, because of weak legal action against perpetrators of illegal fishing crimes and the vast area of Indonesian marine waters. Moreover, limited supervision has made illegal fishing carried out by foreign ships increasingly rampant. To prevent this, it is necessary the holding of the prevention efforts of government and society so that it will not cause a greater impact in the future.
\end{abstract}

Keywords : Illegal fishing; Natuna Sea.

\begin{abstract}
Abstrak
Indonesia merupakan negara dengan wilayah laut yang sangat luas dengan banyaknya keanekaragaman kekayaan laut di dalamnya. Luasnya wilayah laut serta banyaknya kekayaan laut tersebut menyebabkan banyak wilayah laut Indonesia yang sering menjadi tempat tindakan illegal fishing, terutama di daerah laut yang berbatasan langsung dengan negara lain. Salah satunya yaitu laut Natuna di Provinsi Kepulauan Riau, Indonesia. Jenis penelitian yang digunakan adalah metode penelitian studi kasus dengan pendekatan deskriptif dalam menguraikan permasalahan yang tengah dihadapi terkait dengan kegiatan Illegal fishing di laut Natuna. Hasil penelitian menunjukkan bahwa kegiatan illegal fishing ini banyak dilakukan oleh warga negara asing dikarenakan lemahnya tindakan hukum pada pelaku kejahatan illegal fishing serta luasnya wilayah perairan laut Indonesia. Selain itu keterbatasan pengawasan telah menimbulkan illegal fishing yang dilakukan oleh kapal-kapal asing semakin merajalela. Untuk mencegah hal tersebut, perlu diadakannya upaya pencegahan dari pemerintah maupun masyarakat agar hal tersebut tidak menyebabkan dampak yang lebih besar kedepannya.
\end{abstract}

Kata Kunci : Illegal fishing; Laut Natuna. 


\section{Aksiologi : Jurnal Pendidikan \\ dan Ilmu Sosial Volume : 2 No.1 (2021) \\ E-ISSN : 2747-2752 / P-ISSN : 2774-5686}

\section{PENDAHULUAN}

Indonesia dikenal sebagai negara yang mempunyai potensi sumber daya alam yang melimpah, khususnya dalam bidang kemaritiman. Disebut sebagai negara bahari dan kepulauan terbesar di dunia, Indonesia dikenal mempunyai perairan laut sekitar 5,8 juta $\mathrm{km}^{2}$ (75 persen dari total wilayah Indonesia) yang terdiri 0,3 juta $\mathrm{km}^{2}$ perairan laut teritorial; 2,8 juta $\mathrm{km}^{2}$ perairan laut nusantara; dan 2,7 juta $\mathrm{km}^{2}$ laut Zona Ekonomi Ekslusif Indonesia (ZEEI). Negara maritim Indonesia memiliki posisi yang sangat strategis. Secara geografis Indonesia diapit antara dua samudera dan dua Benua yaitu Samudera Hindia dan Pasifik serta Benua Asia dan Australia. Dengan posisi yang sangat strategis tersebut membuat Indonesia menjadi jalur yang sangat penting untuk pelayaran nasional maupun internasional. Potensi ini menjadi sebuah permasalahan yaitu illegal fishing (Yunitasari 2020: 2).

Dengan kekayaan sumber daya laut Indonesia yang memiliki keanekaragaman hayati yang sangat beragam, upaya untuk menjaga serta melindungi kelestariannya menjadi sangatlah penting. Keanekaragaman hayati memiliki peran yang sangat penting dalam suatu negara. Keanekaragaman hayati berperan untuk menjaga stabilitas ekosistem, plasma nutfah dan menjadi salah satu sumber ekonomi negara. Keanekaragaman hayati juga sangat berpotensi sebagai obyek industri ekowisata, dengan hal tersebut sangatlah berpeluang untuk mendapatkan sumber devisa negara.

Wilayah perairan laut di Indonesia mempunyai sumber daya perikanan yang melimpah. Hal tersebut membuat pihak asing tertarik untuk dapat menikmati sumber daya tersebut, yaitu melalui kegiatan illegal Fishing. Illegal Fishing merupakan kegiatan yang dilakukan secara ilegal oleh nelayan-nelayan asing dari negara-negara luar Indonesia yang memasuki kawasan perairan Indonesia secara illegal (Budiman 2002: 53). Kegiatan penangkapan ikan secara ilegal tersebut bertujuan untuk meraih keuntungan ekonomi yang tersedia sangat melimpah di kawasan perairan Indonesia yang selanjutnya akan diperjualbelikan di luar Indonesia dan tentunya akan mendapatkan keuntungan yang berlipat ganda.

Potensi illegal fishing terjadi di pulaupulau terluar di Indonesia yaitu di perairan Natuna yang berada di wilayah perairan Samudera Pasifik. Perairan ini terbentang dari Kepulauan Natuna hingga Kepulauaan Lingga di Provinsi Kepulauan Riau. Perairan Natuna berbatasan langsung dengan Laut Natuna Utara, barat laut, dan timur. Perairan Natuna juga berbatasan langsung dengan Selat Karimata di tenggara dan Selat Singapura di arah barat. Pemicu munculnya kegiatan illegal fishing di perairan Natuna disebabkan oleh beberapa faktor.

Oleh karena itu, perlu diketahui terlebih dahulu faktor apa saja yang menyebabkan terjadinya illegal fishing di perairan Natuna, untuk menemukan upaya pencegahan dalam menyikapi hal tersebut. Dengan begitu dapat dirumuskan beberapa alternatif pencegahan yang dapat diupayakan oleh pemerintah maupun masyarat umum.

\section{METODE PENELITIAN}

Dalam penulisan ini penulis menggunakan metode penelitian studi kasus dengan pendekatan deskriptif dalam menguraikan permasalahan yang tengah dihadapi terkait dengan kegiatan Illegal fishing di perairan Natuna. Menurut Susilo Rahardjo dan Gudnanto (2011) penelitian studi kasus adalah metode yang diterapkan untuk memahami individu lebih mendalam dengan dipraktekkan secara integratif dan komprehensif. Penerapannya dalam penelitian kasus ini berfokus pada faktor 
penyebab serta pencegahan dengan memperhatikan praktik yang telah dilakukan di tengah masyarakat serta penanganan yang telah terjadi di lapangan. Selain itu data yang diperoleh menggunakan metode pengumpulan data observasi yang didapat dari dokumen yang ada di Internet serta jurnal.

\section{HASIL DAN PEMBAHASAN}

\section{A. Faktor Penyebab Terjadinya Illegal Fishing di Perairan Natuna}

Dasar laut di Indonesia sangatlah beragam. Segala bentuk topografi dapat dijumpai di dasar laut Indonesia. Seperti paparan dangkal, terumbu karang, lereng curam maupun landai, gunung api di laut palung laut dalam, basin atau pasu yang terkurung dan lain sebagainnya. Hal tersebut menjadikan Lautan Indonesia menjadi wilayah Marine Mega Biodiversity terbesar di dunia. Lautan Indonesia memiliki sumber daya kelautan sekitar $85.707 \mathrm{~km} 2$ terumbu karang atau sekitar 14\% dari luas terumbu karang dunia, lebih dari 700 jenis rumput laut (makro alga), lebih dari 2.500 jenis moluska, lebih dari 450 jenis karang batu, dan lebih dari 1.400 jenis ekinodermata. Diperkirakan jumlah spesies ikan yang hidup di laut Indonesia sebanyak 8500 spesies atau merupakan $45 \%$ dari jumlah spesies yang ada di dunia. Sebanyak 1300 spesies menempati perairan tawar. Dilihat dari jumlah spesies ikan air tawar, Indonesia menempati ranking kedua di dunia setelah Brazil dan pertama di Asia (Budiman 2002: 4).

Melimpahnya sumber daya perikanan tersebut menimbulkan kejahatan illegal fishing yang dilakukan oleh pihak asing di luar wilayah Indonesia. Illegal Fishing yang terjadi di perairan Indonesia tersebut merupakan transnational crime. Hal ini dikarenakan pelaku dari tindakan kejahatan tersebut adalah orang asing yaitu orang yang bukan warga negara Indonesia tetapi melibatkan pihak asing dibelakangnya. Menurut Direktorat Jenderal Pengawasan Sumber Daya Kelautan dan Perikanan, pada Siaran Pers Kementerian Kelautan dan Perikanan, Nomor. SP.346/SJ.5/III/2021. Pada hari Rabu 31 Maret 2021, Kementerian Kelautan dan Perikanan (KKP) dan kejaksaan Republik Indonesia telah melaksanakan penenggelaman 10 kapal illegal fishing di perairan Laut Natuna Utara. Penenggelaman kapal tersebut melibatkan Kejaksaan Negeri Natuna dan Kejaksaan Negeri Karimun. Sepuluh kapal tersebut adalah :

- KNF 7788 TS

- BV 92570 TS

- BV 93160 TS

- BV 92468 TS

- BV 92467 TS

- BV 8909 TS

- BV 92778 TS

- KG 91526 TS

- KG 93811 TS

- KG 93012 TS

Kesepuluh kapal ikan tersebut berbendera Vietnam yang ditangkap di perairan WPPNRI 711 Laut Natuna Utara. Dengan adanya tindakan penenggelaman 10 kapal di Laut Natuna semakin menguatkan bahwa aparat Indonesia akan bertindak tegas terhadap para pencuri ikan atau illegal fishing di wilayah Indonesia.

Dari kasus tersebut didapati beberapa faktor penyebab maraknya kegiatan illegal fishing di perairan Natuna yaitu :

1. Lemahnya Sarana dan Prasaran Pengawasan Aparat di Laut Indonesia. 
Susi Pudjiastuti mengatakan bahwa penyebab aksi illegal fishing yaitu lemahnya kondisi pengawasan dan keamanan di wilayah perairan Indonesia. Akibat dari lemahnya pengawasan di perairan Indonesia, para nelayan asing dengan mudahnya datang ke Indonesia terutama negara-negara perbatasan yang mudah sekali menembus wilayah perairan Indonesia untuk mengambil ikan secara illegal. Jika semakin lemah sikap aparat yang berkewajiban mengawasi laut Indonesia maka akan berakibat maraknya kasus illegal fishing yang akan terjadi di perairan Indonesia.

2. Lemahnya Penegakan Hukum di Laut Indonesia

Kedaulatan Indonesia saat ini masih dipandang sebelah mata oleh semua pihak. Dibuktikan dengan adanya daerah laut yang jarang terjamah oleh patroli aparat TNI Angkatan Laut maupun Polisi Air. Dengan adanya fakta tersebut sangat mengkhawatirkan kondisi kelautan di Indonesia. Kondisi yang mengkhawatirkan tersebut membuat tidak terkendalinya tindak kejahatan di perairan Indonesia salah satunya yaitu dengan kegiatan illegal fishing.

\section{Tingkat Konsumsi Ikan Global Semakin Meningkat}

Ikan mengandung sumber protein tinggi dan sangat baik dikonsumsi oleh manusia. Dengan adanya khasiat dari ikan tersebut membuat ikan banyak memiliki peminat baik konsumen di Indonesia maupun di dunia. Menurut Badan Karantina Ikan, Pengendalian Mutu dan Keamanan, hasil nilai ekspor perikanan Indonesia memperlihatkan peningkatan setiap tahunnya. Pada 2019, nilai ekspor hasil perikanan Indonesia mencapai Rp73.681.883.000 dimana nilai tersebut meningkat sebesar $10,8 \%$ dibandingkan dengan periode tahun 2018 yaitu senilai
Rp66.487.580.000. Terkait Volume Ekspor untuk Komoditi Perikanan Konsumsi Hidup Pada Tahun 2019, lebih tinggi $24 \%$ dibanding pada Tahun 2018. Sedangkan Untuk Komoditi Perikanan Konsumsi Non Hidup pada Tahun 2019 lebih tinggi $27 \%$ dibanding pada tahun 2018. Volume Ekspor untuk Komoditi Perikanan Non Konsumsi Hidup Pada Tahun 2019, lebih tinggi 21 \% dibanding pada Tahun 2018. Sedangkan Untuk Komoditi Perikanan Non Konsumsi Non Hidup pada Tahun 2019 terjadi kenaikan sebesar $47 \%$ dibanding pada periode yang sama tahun 2018.

\section{Over Fishing}

Over Fishing atau penangkapan ikan berlebihan di laut merupakan salah satu bentuk eksploitasi secara berlebihan yang membahayakan popuasi ikan di laut. Para nelayan melakukan tindakan penangkapan ikan sebanyak-banyaknya dan jika tidak para nelayan lain yang akan menangkap ikan-ikan di laut. Akibat dari adanya tindakan over fishing membuat para nelayang melakukan segala cara yang dapat merusak populasi sumber daya laut. Akibat dari adanya over fishing bahan peledak menjadi senjata utama untuk melakukan penangkapan ikan. Hal tersebut menyebabkan kematian untuk ikan-ikan kecil, ikan-ikan besar, terumbu karang, dan biota laut lainnya.

\section{B. Upaya Pencegahan yang dapat Dilakukan dalam Menyikapi llegal Fishing di Perairan Natuna.}

Salah satu fungsi hukum di Indonesia yaitu untuk mencapai sebuah tujuan sebagaimana yang tertuang dalam pembukaan UUD 1945 yakni melindungi segenap bangsa Indonesia dan seluruh tumpah darah Indonesia. Berdasarkan hal tersebut, pemerintah memiliki tugas untuk menciptakan instrumen sosial untuk melindungi segenap bangsa Indonesia dari 
berbagai tindakan yang menimbulkan kerugian. Dalam upaya penanggulangan kejahatan, aspek kriminologisnya sangat diperlukan untuk menyusun program pencegahan kejahatan oleh penegak hukum. Oleh karena itu mencari faktor-faktor yang menyebabkan kejahatan tersebut diperlukan agar dapat digunakan untuk menyusun program penanggulangan kejahatan yang diarahkan kepada penggarapan faktor-faktor yang bersangkutan.

Kriminologi merupakan ilmu pengetahuan yang mempelajari tentang kejahatan. Secara etimologi kriminologi berasal dari kata "Crime" yang berarti kejahatan dan "logos" yang berarti pengetahuan atau ilmu pengetahuan, sehingga kriminologi adalah ilmu tentang kejahatan atau penjahat. Menurut P.Topinar. Sthepen Hurwitz, kriminologi dipandang sebagai bagian dari criminal scaince yang dengan penelitian empiris atau nyata berusaha memberikan gambaran tentang faktor-faktor kriminalitas (Hurwitz 1982: 7). Namun dalam menafsirkan, menganggapi dan menjelaskan sebuah fenomena suatu kejahatan sangat bergantung pada penafsiran seseorang yang akan mempengaruhi wujud penjelasan maupun teori yang dihasilkannya.

Menurut Baharuddin Lopa, mengutip pendapat Kaiser di dalam buku Crime Prevention Strategies in Erope and North America yang disusun John Graham, 1990, mengatakan bahwa strategi pokok untuk mencegah kejahatan dapat dibagi tiga kelompok, yaitu primary, secondary dan tertiary prevention (Lopa 1996: 220). Selanjutnya menurut beliau primary prevention lah yang dianggap paling efektif. Hal ini dikarenakan jika ingin mencegah suatu tindakan kejahatan, maka penyebabnya yang perlu di hilangkan terlebih dahulu.
Terlepas dari banyaknya faktor yang menyebabkan banyaknya tindakan pencurian ikan di laut Natuna, namun hal tersebut tentu dapat dicegah dengan beberapa cara. Walaupun tindakan pencegahan ini tidak semuanya dirasa efektif untuk menangani tindakan pencurian ikan di laut Natuna secara keseluruhan. Namun cukup untuk mengurangi tindakan tersebut serta memberikan efek jera dan peringatan baik kepada pelaku tindak pidana pencurian ikan, maupun masyarakat umum agar tidak melakukan hal yang sama.

Berikut merupakan beberapa upaya yang telah atau dapat dilakukan oleh pemerintah dalam mengatasi tindakan illegal fishing :

1) Memperketat Penjagaan di Wilayah Rawan Pencurian

Dalam hal ini pemerintah terutama Kementrian Kelautan dan Perikanan memiliki peran penting untuk mengerahkan pasukan polisi laut untuk berpatroli secara rutin dan memperketat pengawasannya di kawasan laut Indonesia. Pengawasan tersebut tidak hanya dilakukan di daerah yang langsung berbatasan dengan laut negara lain saja, tetapi juga di kawasankawasan-kawasan strategis yang sering menjadi daerah terjadinya tindakan illegal fishing.

Dengan diadakannya patroli secara rutin tentu saja dapat menekan jumlah kapal yang melakukan Tindakan illegal Fishing. Tidak hanya itu, dengan diadakannya pengetatan pengawasan di daerah laut juga dapat mengurangi terjadinya tindakan penangkapan ikan yang tidak sesuai dengan ketentuan yang berlaku seperti penggunaan barang peledak atau pukat harimau untuk menangkap ikan atau dengan cara-cara lain yang tidak mengidahkan aturan dalam penangkapan ikan. Cara ini dianggap cukup efektif dikarenakan apabila ada kapal asing atau 
kapal yang terlihat sedang melakukan kegiatan eksploitasi laut dapat segera ditangkap untuk kemudian ditindaklanjuti oleh badan yang berwenang. Namun untuk memaksimalkan pengawasan tersebut diperlukan banyak armada kapal laut dan juga biaya yang tidak sedikit dalam pelaksanaannya.

2) Pemberian sanksi yang Tegas Terhadap Pelaku Pencurian

Pemerintah Indonesia sendiri telah menerapkan peraturan internasional maupun nasional dalam menganggulangi serta mencegah adanya tindakan illegal fishing di wilayah perairan Indonesia. Salah satunya yaitu dengan meratifikasi UNCLOS 1982 dengan diundangkannya UU No.17 Tahun 1985 tentang Pengesahan UNCLOS Tahun 1982. Walaupun illegal fishing tidak secara eksplisit tercantum dalam UNCLOS 1982, namun wacana tentang ilegal fishing tertera dalam kerangka IUU Fishing pada saat diselenggarakannya forum Commision for Conservation of Atlantic Marine Living Resources (CCAMLR) pada 27 Oktober -7 November 1997. Selain itu pemerintah juga membuat beberapa peraturan-perundangundangan terkait dengan kegiatan Illegal fishing di perairan Indonesia salah satunya adalah Undang-Undang No.45 Tahun 2009 tentang Perubahan Atas Undang-Undang No.31 Tahun 2004 tentang Perikanan.

Dalam undang-undang No.45 Tahun 2009 dalam Pasal 69 ayat (4) menyatakan bahwa Dalam melaksanakan fungsi sebagaimana dimaksud pada ayat (1) penyidik dan/ atau pengawas perikanan dapat melakukan tindakan khusus berupa pembakaran dan/ atau penenggelaman kapal perikanan yang berbendera asing berdasarkan bukti permulaan yang cukup. Berdasarkan pasal tersebut disebutkan bahwa tindakan penenggelaman ataupun pembakaran kapal berbendera asing dapat dilakukan oleh aparat yang berwenang

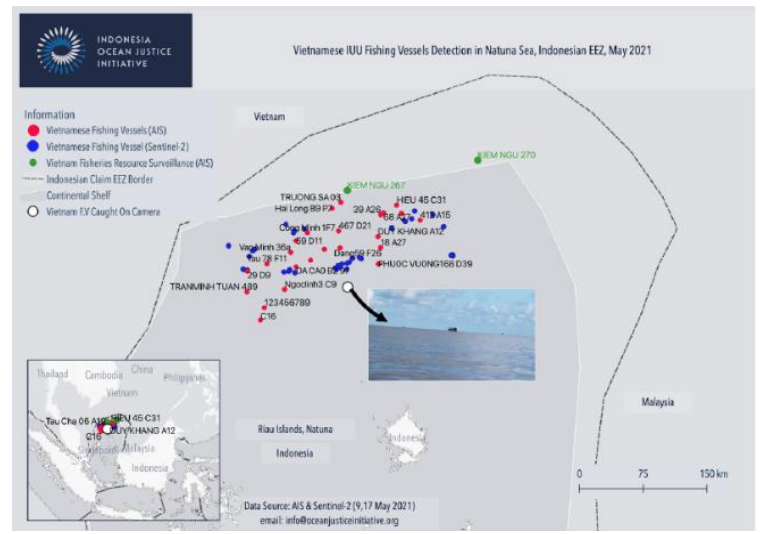

apabila terdapat bukti yang cukup bahwa kapal tersebut melakukan tindakan illegal fishing di perairan Indonesia. Dalam hal ini pemerintah Indonesia telah beberapa kali melaksanakan sanksi tersebut yang dilakukan oleh pihak yang berwenang di perairan Natuna. Berdasarkan data yang ada, Kementerian Kelautan dan Perikanan serta Kejaksaan RI telah memusnahkan 26 kapal ikan asing ilegal di Batam, Aceh, Pontianak dan Natuna, sepanjang tahun 2021. Upaya ini dilakukan untuk memberikan efek jera serta peringatan yang tegas terhadap tindakan illegal fishing di daerah Perairan Indonesia. Selain tindakan penenggelaman kapal secara langsung pelaku juga dikenai sanksi berupa denda sejumlah dengan apa yang tertera dalam undang-undang tersebut.

Dalam penegakkan pelaksanaannya peraturan perundang-undangan, pemerintah Indonesia sudah dapat dikatakan sudah memadai dilihat dari banyaknya kapal yang sudah tertangkap serta diberikan sanksi yang tegas dengan ditenggelamkannya kapal-kapal tersebut. Namun terlepas dari hal tersebut tidak dapat dipungkiri bahwa dengan luasnya laut wilayah Indonesia menyebabkan adanya beberapa kapal yang tidak tertangkap. Selain itu terbatasnya sarana dan prasarana yang dimiliki untuk menangkap menyebabkan masih banyak kapal-kapal yang melakukan illegal fishing di kawasan perairan 
Indonesia, terutama laut yang berbatasan langsung dengan negara-negara lain.

\section{3) Pemanfaatan Perkembangan Teknologi}

Saat ini Indonesia telah menerapkan penggunaan Automatic Identification System (AIS) yang terdapat dalam perangkat lunak Marine Traffic dan juga penggunaan satelit untuk mendeteksi kegiatan penangkapan ikan yang dilakukan oleh kapal-kapal asing di daerah Perairan Natuna. Dengan digunakannya teknologi ini kapal-kapal asing dapat kemudian di identifikasi nama, asal serta titik koordinat dimana tempat penangkapan ikan tersebut terjadi.

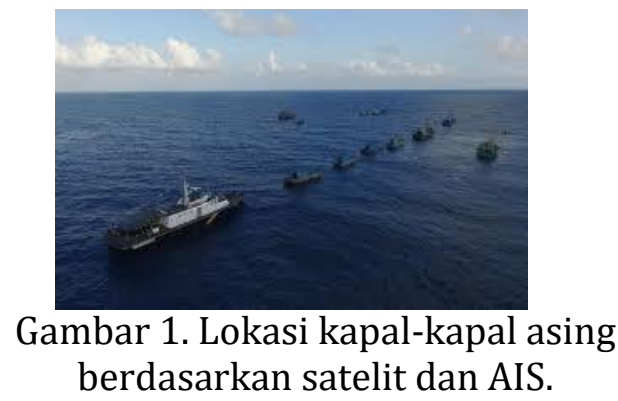

Berdasarkan gambar tersebut dapat diamati bahwa masih terdapat banyak praktik Illegal fishing yang dilakukan oleh negara lain ditunjukkan dengan banyaknya titik-titik merah dan biru pada gambar tersebut, terutama di kawasan laut Natuna utara. Dengan dimanfaatkannya teknologi ini tentu membantu dalam mendeteksi daerah-daerah yang sering menjadi tempat kegiatan pencurian ikan. Sehingga kemudian dapat dilakukan tindakan pengetatan penjagaan dan pengawasan di daerah tersebut. Tentu hal ini sangat membantu kinerja polisi laut untuk berpatroli ke daerah-daerah yang rawan akan pencurian ikan. Kalaupun kapal tersebut lolos dari patroli yang dilakukan polisi laut, nama serta nomor kapal tersebut dapat diidentifikasi untuk kemudian dijadikan bukti untuk ditindaklanjuti oleh petugas yang berwenang.

\section{KESIMPULAN}

Maraknya kegiatan illegal fishing di laut Natuna dikarenakan lemahnya tindakan hukum terhadap pelaku kejahatan illegal fishing serta luasnya wilayah perairan laut Indonesia. Selain itu keterbatasan pengawasan menimbulkan illegal fishing yang dilakukan oleh kapal-kapal asing semakin merajalela. Namun dapat dilakukan beberapa upaya pencegahan dalam memerangi tindakan illegal fishing di perairan Natuna diantaranya yaitu partisipasi seluruh masyarakat sekitar. Tidak hanya pemerintah yang bertanggung jawab untuk menangani Illegal fishing dengan cara meneggakkan sanksi yang tegas serta aparat pemerintah yang berpatroli di daerah-daerah rawan pencurian, tetapi juga masyarakat umum memiliki peran yang penting untuk ikut serta menjaga perairan laut Natuna dengan cara ikut terlibat dengan cara apabila melihat atau mengetahui adanya tindakan illegal fishing yang terjadi di wilayah laut Natuna dapat segara melapor kepada pihak yang berwenang. Dengan adanya kerjasama ini tindakan illegal fishing dapat dicegah bahkan mengurangi tingkat pencurian ikan di wilayah perairan Natuna.

\section{DAFTAR PUSTAKA}

\section{$\underline{B u k u}$}

Hurwitz, Sthephan. 1982. Kriminologi, Saduran Ny.L.Moeljatno. Jakarta : Bina Aksara.

Lopa, Baharuddin. 1996. Mencegah Kejahatan, Anatomi Kejahatan di Indonesia. Bandung : Granesia.

Jurnal

Budiman, A, Arief AJ \& Tjakrawidjaya AH. 2002. "Museum Zoologi dalam Penelitian dan Konservasi 
Keanekaragaman Hayati (Ikan)." Jurnal Iktiologi Indonesia 2(2): 51-55.

Hartono, Made Sugi \& Diah Ratna Sari Hariyanto. 2018. “Kajian Kriminologi Terhadap Tindak Pidana Perikanan Di Kecamatan Nusa Penida." Jurnal Kertha Wicaksana 1 (1): 11-21.

Kurnia, Ida. 2021. "Law Enforcement Against Illegal Fishing In Natuna Waters During The Covid-19 Pandemic." Jurnal Res Nullius Law Journal 3 (2): 178-196.

Muliadi, Saleh. 2012. "Aspek Kriminologis Dalam Penanggulangan Kejahatan." Jurnal Fiat Justitia 6 (1): 1-11.

Tama, Nandio Bagus. 2019. "Tindak Pidana Illegal Fishing Dalam Kajian Hukum Pidana Indonesia dan Kriminologi." Dinamika Jurnal Ilmiah Ilmu Hukum 25(9): 1-10.

Yunitasari, Desi. 2020. "Penegakan Hukum di Wilayah Laut Indonesia Terhadap Kapal Asing Yang Melakukan Illegal Fishing Mengacu Pada Konvensi United Nations Convention On Law Of The Sea 1982." Jurnal Pendidikan Kewarganegaraan Undiksha 8(1): 118.

Internet

Indonesia Ocean Justice Iniative. 2021. "IUU Fishing Di Laut Natuna Utara - Mei 2021". https://oceanjusticeinitiative.org/2021/06 114/iuu-fishing-di-laut-natuna-utara-mei2021/ , diakses pada 1 September 2021.

Putra, Idris Rusadi. KKP dan Kejaksaan Tenggelamkan 10 Kapal Pencuri Ikan di Laut Natuna,m.merdeka.com, https://www.google.com/amp/s/m.merde ka.com/amp/uang/kkp-dan-kejaksaantenggelamkan-10-kapal-pencuri-ikan-dilaut-natuna.html, diakses pada 3 september 2021.

Peraturan Perundang-Undangan
Undang-Undang Nomor 17 Tahun 1985 tentang Pengesahan United Nation Convention on the Law of the Sea 1982.

Undang-Undang Nomor 45 Tahun 2009 tentang Perubahan Atas Undang-Undang Nomor 31 Tahun 2004 tentang Perikanan. 